\title{
Soil and tree water relations in mature oak stands of northern Germany differing in the degree of decline
}

\author{
FM Thomas *, G Hartmann \\ Niedersächsische Forstliche Versuchsanstalt, Grätzelstr 2, \\ 37079 Göttingen, Germany
}

(Received 6 September 1994; accepted 27 June 1995)

\begin{abstract}
Summary - At three sites in northern Germany in which oak decline occurred during the last decade, the impact of soil water conditions on oak damage was investigated in one healthy and one declining stand of pedunculate or sessile oak, respectively (Quercus robur $L$ and $Q$ petraea [Matt] Liebl). Soil matric potentials were determined with tensiometers, and xylem water potentials as well as relative water content and osmotic pressure of the leaves were measured in oaks differing in the degree of damage. Additionally, the distribution and biomasses of fine roots were investigated. More negative soil matric potentials in the declining stand of pedunculate oak and lower relative water contents of the leaves of damaged trees even in a vegetation period with sufficient precipitation indicated a higher risk of drought stress in dry years. At the two sites with sessile oaks, the impact of drought on tree water relations seemed to be much smaller. The relative water content of leaves from damaged oaks was not lower than of those from healthy trees, even in an extremely warm and dry period. At these sites, crown reduction may be a temporary form of adaptation to insufficient water supply and, in this case, would have to be differentiated from "oak decline" in its true sense. Generally, distinct reductions in fine root biomass and an increased percentage of dead fine roots were detected only in severely damaged trees, indicating that root decay is not a primary factor in the complex of oak decline.
\end{abstract}

\section{oak decline / Quercus / relative water content / root / soil / water potential}

Résumé - Régime hydrique du sol et des arbres dans des peuplements de chênes adultes en Allemagne du Nord présentant différents degrés de dommage. Dans trois sites de l'Allemagne du Nord où on a constaté au cours des dix dernières années le dépérissement de chênes, on a analysé l'influence du régime hydrique du sol sur l'endommagement des chênes dans un peuplement sain et dans un peuplement endommagé de chênes pédonculés (Quercus robur $L$ ) ou de chênes sessiles $(Q$ petraea [Matt] Liebl). Les potentiels hydriques des sols ont été déterminés à l'aide de tensiomètres. On a mesuré les potentiels hydriques du xylème ainsi que la teneur en eau relative et la pression osmotique des feuilles sur des chênes présentant un degré d'endommagement différent. On a en outre

* Present address: Universität Göttingen, Systematisch-Geobotanisches Institut, Untere Karspüle 2, 37073 Göttingen, Germany 
analysé la distribution et la biomasse de racines fines. Des potentiels hydriques du sol plus négatifs dans le peuplement endommagé des chênes pédonculés et des teneurs en eau relatives plus faibles dans les feuilles d'arbres endommagés, même dans une période de végétation avec suffisamment de précipitations, ont indiqué un risque plus élevé de stress hydriques dans les années sèches. Dans les deux sites où se trouvaient les chênes sessiles l'influence de la sécheresse sur le régime hydrique était beaucoup plus faible. La teneur en eau relative des feuilles de chênes endommagés n'était pas moins basse que dans les feuilles des arbres sains, même dans une phase extrêmement chaude et sèche. Dans ces sites, la réduction des couronnes est peut-être l'expression temporaire d'une adaptation à un approvisionnement en eau insuffisant et serait dans ce cas à différencier du "dépérissement de chênes" au sens propre. En général, on n'a trouvé une réduction distincte de la biomasse des racines fines et des pourcentages élevés de racines fines mortes que sur des arbres fortement endommagés, ce qui indique que les détériorations des racines ne sont pas un facteur primaire d'endommagement dans le complexe du dépérissement des chênes.

dépérissement de chêne / potentiel hydrique / Quercus / racine / sol / teneur en eau relative

\section{INTRODUCTION}

In northern Germany, several outbreaks of oak decline (pedunculate oak, Quercus robur L; and sessile oak, $Q$ petraea (Matt) Liebl) occurred during the last 250 years. A comprehensive description of the single events is given by Hartmann and Blank (1992). In this century, drought was one of the primary factors at least in the oak decline of 1911-1920. Also in other parts of Europe, drought was part of the primary causal complex of the decline of oak stands (cf Delatour, 1983; Schlag, 1994). Extreme droughts can trigger oak decline without contribution of other factors. A striking example is the extreme drought of 1976 in France which led to severe damage, particularly in pedunculate oak (Becker and Lévy, 1982).

In northern Germany, the present decline started in 1982/83, resulting in severe growth reductions and a mortality rate of at least two to five trees per hectare and year (Hartmann and Blank, 1992, 1993). Growth reductions coincided with the occurrence of drought, winter frost and insect defoliation which are, thus, considered as possible predisposing factors of oak decline (Hartmann and Blank, 1992, 1993; Thomas and Büttner, 1993). Eisenhauer (1989) postulated an accumulation of precipitation deficits over several years to be the primary cause for the decline of sessile oak stands in a forest district of northeastern Germany. Surveys of more than 2500 oak stands in Lower Saxony (northwestern Germany) by CIRaerial photography revealed most crown damage to occur on forest sites with stagnant or intermittent soil moisture conditions (Ackermann and Hartmann, 1992). To test the effect of soil water relations on the degree of damage in sessile and pedunculate oaks, investigations were carried out in three regions of northern Germany which belong to the centres of oak decline. The sites covered the range of climatic conditions in the lowland of northern Germany (oceanic to subcontinental) and differed in soil texture (clay/loess/sand). The following parameters were determined: i) soil matric potentials in adjacent oak stands differing in the degree of decline; ii) xylem water potentials, relative water contents (RWC) and the osmotic pressure of leaves from oaks differing in the degree of damage; iii) biomasses of living and dead fine roots of oaks differing in the degree of damage. It was assumed that effects of primary causal factors should be already detectable in moderately damaged trees exhibiting initial symptoms (crown thinning), while effects of secondary factors should be found only in severely damaged trees showing advanced symptoms (dieback, reduction of annual ring width). 


\section{MATERIALS AND METHODS}

The investigations were carried out at the Niedersächsische Forstliche Versuchsanstalt (Lower Saxony Forest Research Station), Göttingen.

\section{Investigation sites}

The studies were performed at three sites in northern Germany differing in climate and subsoil (table 1). The stands in Neuenburg grew on a site well suitable for pedunculate oak, whereas the other stands were typical for the plantation of sessile oak for edaphic (Sprakensehl) or climatic (Hakel) reasons, respectively. All stands originated from natural regeneration. At each site, two adjacent stands were compared, each covering about 2 ha. One of each pair, named the "declining" stand, showed at least five damaged trees per hectare. These were subdivided into moderately damaged oaks (<60\% leaf loss) and severely damaged oaks ( $>60 \%$ leaf loss and dieback). In the "healthy" stand, most trees were without visible symptoms (0-25\% leaf loss). Apart from crown thinning in the damaged oaks, no visible symptoms of injury (caused by insects or pathogens) could be detected at the trees selected.

The damaged and the healthy stands differed in the exploitable water stock (cf table I), mainly due to different soil texture. In Neuenburg, the dense clay layer of the subsoil was covered by a layer of sandy soil which was about $50 \mathrm{~cm}$ thick in the healthy stand, but only ca $30 \mathrm{~cm}$ thick in the declining stand. In Sprakensehl, small clay layers were scattered in the sandy subsoil of both stands. In the damaged stand, this led to a considerable variation in the exploitable water stock. In the Hakel Forest, the subsoil of the healthy stand had a relatively high clay content which resulted, to a certain extent, in a reduction of the exploitable water stock. The subsoil of the damaged stand (below $44 \mathrm{~cm}$ ) consisted of weathered limestone, but fine roots were found down to a depth of $100 \mathrm{~cm}$. Due to its low content of fine earth, however, the subsoil of this stand did not contribute much to the exploitable water stock which was, calculated for the rooting depth, distinctly lower than in the healthy stand.

In the Hakel Forest, considerable insect defoliation caused by Tortrix viridana $L$ occurred in May 1993. At the first date of xylem water potential measurement, however, the foliage was reestablished by leaves from replacing shoots (not from Lammas shoots).

\section{Soil matric potentials}

The soil matric potentials were determined with soil tensiometers. A tensiometer consisted of a ceramic candle (type P80, KPM, Berlin), connected with a water-filled PVC tube of the desired length. The range of measurement was 0 to -850 $\mathrm{hPa}$. The years of measurement and the number of tensiometers per stand and soil depth are given in table II. In Neuenburg, the tensiometers were installed within an area of ca $30 \mathrm{~m} * 10 \mathrm{~m}$. In 1993, soil matric potentials were measured additionally at the eastern and western sides of trees selected for the determination of xylem water potential (cf Xylem water potentials, relative water contents and osmotic pressure). The measurements were performed in $1 \mathrm{~m}$ stem distance where the concentrations of fine roots were found to be highest (cf Root distribution, biomass and vitality). Since the variability of matric potentials within a stand had proven to be relatively low (apart from very dry periods when some of the tensiometers were out of range), the number of tensiometers could be slightly reduced in the stands of the Hakel Forest. In these stands, the tensiometers were placed within an area of about $20 \mathrm{~m} * 10 \mathrm{~m}$. Since the subsoil of the declining stand consisted mainly of poorly weathered limestone, matric potentials were determined only down to $40 \mathrm{~cm}$ soil depth. Because of the variation in soil texture within the stands (cf Investigation sites), matric potentials in Sprakensehl were measured adjacent to single trees selected for the determination of xylem water potentials. Tensiometers were installed at $1 \mathrm{~m}$ stem distance.

The matric potentials were determined with a pressure gauge (precision $\pm 1 \mathrm{hPa}$; Thies, Göttingen). In Neuenburg, measurements were taken biweekly in 1992 and weekly in 1993 (from April to November). In the Hakel Forest and in Sprakensehl, data were taken in intervals of about 10 days (from April to October).

For calculation of the soil matric potential, the negative values measured had to be corrected by adding the gravitational potential. If a positive value resulted from the calculation, this was taken as an indication of stagnant moisture. In this case, the depth of stagnant moisture was calculated according to: 


$$
x[\mathrm{~cm}]=\left(P s i_{G}-P s i_{M}\right) * 1 \mathrm{~cm} / 0.981 \mathrm{hPa}
$$

where $x=$ depth of stagnant moisture; $P{ }^{P} j_{G}=$ gravitational potential of the water column in the tensiometer $[\mathrm{hPa}] ; \boldsymbol{P S}_{\mathrm{M}}=$ calculated positive matric potential $[\mathrm{hPa}]$.

\section{Xylem water potentials, relative water contents and osmotic pressure}

The number of the trees investigated per stand and the dates of measurement are given in table

Table I. Geographic and climatic features and site characteristics of the oak stands investigated. Meteorological data are derived from the stations in Varel, Uelzen (ca $21 \mathrm{~km}$ northwest of Sprakensehl) and Cochstedt ( $5 \mathrm{~km}$ east of the stands in the Hakel Forest [annual precipitation]), operated by the Deutscher Wetterdienst (German meteorological service) (average values of 1951-1980).

\begin{tabular}{|c|c|c|c|}
\hline Location & Varel & Sprakensehl & Heteborn/Hakel Forest \\
\hline Forest district & Neuenburg & Sprakensehl & Pansfelde \\
\hline Growth area & Coastal plain & $\begin{array}{l}\text { Heathland } \\
\text { (Lüneburger } \\
\text { Heide) }\end{array}$ & $\begin{array}{l}\text { Lee side of the } \\
\text { Harz } \\
\text { Mountains }\end{array}$ \\
\hline $\begin{array}{l}\text { Latitude } \\
\text { Longitude }\end{array}$ & $\begin{array}{l}52^{\circ} 23^{\prime} \mathrm{N} \\
8^{\circ} 08^{\prime} \mathrm{E}\end{array}$ & $\begin{array}{l}52^{\circ} 47^{\prime} \mathrm{N} \\
10^{\circ} 25^{\prime} \mathrm{E}\end{array}$ & $\begin{array}{l}51^{\circ} 53^{\prime} \mathrm{N} \\
11^{\circ} 19^{\prime} \mathrm{E}\end{array}$ \\
\hline Elevation above sea level (m) & 10 & 115 & 200 \\
\hline Annual precipitation (mm) & 801 & 618 & 508 \\
\hline Annual mean temperature $\left({ }^{\circ} \mathrm{C}\right)$ & 8.6 & 8.3 & $8.7^{\mathrm{a}}$ \\
\hline Oak species & Pedunculate oak & Sessile oak & Sessile oak \\
\hline Tree age (in 1994) (years) & 180 & 99 & ca 170 \\
\hline Soil parent material & $\begin{array}{l}\text { Clay under } \\
\text { glacial loamy } \\
\text { sand }\end{array}$ & Glacial sand & $\begin{array}{l}\text { Limestone and } \\
\text { sandstone } \\
\text { under loess }\end{array}$ \\
\hline \multicolumn{4}{|l|}{$\begin{array}{l}\text { Soil type } \\
\text { (FAO classification) b }\end{array}$} \\
\hline Healthy stand & Gleyic cambisol & $\begin{array}{l}\text { Spododystric } \\
\text { cambisol }\end{array}$ & Luvisol \\
\hline Damaged stand & Gleysol & $\begin{array}{l}\text { Spododystric } \\
\text { cambisol }\end{array}$ & Luvisol \\
\hline \multicolumn{4}{|l|}{ Rooting depth } \\
\hline Healthy stand $(\mathrm{cm})$ & 105 & 105 & ca 100 \\
\hline Damaged stand $(\mathrm{cm})$ & 105 & 105 & 100 \\
\hline \multicolumn{4}{|l|}{ Exploitable water stock ${ }^{c}$} \\
\hline Healthy stand (mm) & 181 & 135 & $\begin{array}{l}157 \\
118\end{array}$ \\
\hline Damaged stand $(\mathrm{mm})$ & 137 & $122-175$ & 118 \\
\hline
\end{tabular}

\footnotetext{
a Data from Eisenhauer (1989); ${ }^{\mathrm{b}}$ according to Schachtschabel et al (1984); c calculated according to Arbeitskreis Standortskartierung (1980), on the basis of field classification and chemical analysis of the $\mathrm{C}$ concentration of the soil.
} 
Table II. Number of tensiometers for soil matric potential measurements installed in different soil depths at the investigation sites.

\begin{tabular}{|c|c|c|c|c|c|}
\hline Site and year of measurement & $15 \mathrm{~cm}$ & $40 \mathrm{~cm}$ & $60 \mathrm{~cm}$ & $100 \mathrm{~cm}$ & Total \\
\hline \multicolumn{6}{|l|}{ Neuenburg, $1992+1993$} \\
\hline Healthy stand & 12 & 12 & - & 12 & 36 \\
\hline Declining stand & 12 & 12 & - & 12 & 36 \\
\hline \multicolumn{6}{|l|}{ Neuenburg, 1993} \\
\hline Healthy oak, healthy stand (1 tree) & 2 & 2 & - & 2 & 6 \\
\hline Healthy oaks, declining stand ( 3 trees) & 2 per tree & 2 per tree & - & 2 per tree & 6 per tree \\
\hline Damaged oak, healthy stand ( 1 tree) & 2 & 2 & - & 2 & 6 \\
\hline $\begin{array}{l}\text { Damaged oaks, declining stand ( } 3 \text { trees; } \\
2 \text { moderately, } 1 \text { severely damaged) }\end{array}$ & 2 per tree & 2 per tree & - & 2 per tree & 6 per tree \\
\hline \multicolumn{6}{|l|}{ Hakel, 1993} \\
\hline Healthy stand & 10 & 10 & 10 & 10 & 40 \\
\hline Declining stand & 10 & 10 & - & - & 20 \\
\hline \multicolumn{6}{|l|}{ Sprakensehl, 1994} \\
\hline Healthy oaks, healthy stand (2 trees) & 3 per tree & 3 per tree & - & 3 per tree & 9 per tree \\
\hline Healthy oaks, declining stand (2 trees) & 3 per tree & 3 per tree & - & 3 per tree & 9 per tree \\
\hline $\begin{array}{l}\text { Damaged oaks, healthy stand ( } 2 \text { trees; } \\
1 \text { moderately, } 1 \text { severely damaged) }\end{array}$ & 3 per tree & 3 per tree & - & 3 per tree & 9 per tree \\
\hline Damaged oaks, declining stand ( 2 trees) & 3 per tree & 3 per tree & - & 3 per tree & 9 per tree \\
\hline
\end{tabular}

III. From each tree to be investigated, three branches from different positions within the upper crown were harvested by tree climbers at predawn and, dry weather conditions provided, in the afternoon between 1400 and 1600 hours when water potentials were presumed to be minimal (Backes, 1991). Until measurement (not later then $4 \mathrm{~h}$ after harvest), the branches were kept in closed plastic bags. Measurements had shown that changes in water potential did not occur during this time. Predawn water potentials (PWP) and afternoon water potentials (AWP) were measured with a pressure chamber (Scholander method) in five to six primary shoots from each branch, comprising three or four leaves. Mean values were calculated for each branch. For comparison of healthy and damaged oaks, a mean value, from the mean values of the respective branches, was calculated for each tree which was computed for the stem base by taking the gravitational potential into account.

For the determination of the relative water content (RWC), leaves from the branches harvested for water potential measurement were put in small plastic bags and transported to the laboratory in a cold box. The RWC was measured in leaf disks according to Slavík (1974, p 146). The leaf disks ( $1 \mathrm{~cm}$ diameter) were saturated with water vapour for $3 \mathrm{~h}$ in a wet sheet of foam material. Ten disks were combined to calculate one RWC value. For each branch harvested, three RWC values (branches sampled in the afternoon: two values) were determined. For comparison of the trees, a mean value for each tree was calculated from the mean values of the respective branches.

The osmotic pressure of the cell sap of leaves from branches harvested for the water potential measurements were determined in samples from Neuenburg (end of July 1993) and Sprakensehl (July and mid-August 1994). Leaves were transported to the laboratory in a cold box and pressed in a hydraulic press at $3 \mathrm{MPa}$. The osmotic pressure of the expressed sap was measured on the basis of depression of freezing point with a cryoscope (Advanced Wide Range Osmometer, type III W 2; Advanced Instruments, Needham Heights, MA, USA). One value per branch was determined. 
Table III. Number of trees for determination of xylem water potential and relative water content at the investigation sites, and dates of measurement.

\begin{tabular}{|c|c|c|c|c|c|}
\hline \multirow[t]{2}{*}{ Site } & \multicolumn{2}{|c|}{ Healthy stand } & \multicolumn{2}{|c|}{ Declining stand } & \multirow[t]{2}{*}{ Date } \\
\hline & $\begin{array}{l}\text { Healthy } \\
\text { oaks }\end{array}$ & $\begin{array}{l}\text { Damaged } \\
\text { oaks }\end{array}$ & $\begin{array}{l}\text { Healthy } \\
\text { oaks }\end{array}$ & $\begin{array}{l}\text { Damaged } \\
\text { oaks }\end{array}$ & \\
\hline$\ldots$ & --- & 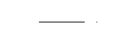 & - & & \\
\hline Neuenburg & 1 & 1 & 3 & $3^{a}$ & $\begin{array}{l}\text { 1993: } 17-18 \text { June; } 28-29 \text { July; } \\
8-9 \text { and } 20-22 \text { Sept }\end{array}$ \\
\hline Hakel/Pansfelde & 2 & - & 3 & 3 & $\begin{array}{l}\text { 1993: } 1-2 \text { and } 21-22 \text { July; } \\
\text { 18-20 Aug; } 14-16 \text { Sept }\end{array}$ \\
\hline Sprakensehl & 2 & $2^{a}$ & 2 & 2 & $\begin{array}{l}\text { 1994: } 14-15 \text { June; } 6-7 \text { and } \\
26-27 \text { July; } 15-17 \text { Aug }\end{array}$ \\
\hline
\end{tabular}

a One of these trees severely damaged.

\section{Root distribution, biomass and vitality}

The trees selected for root investigations were not identical with those for water potential measurements. Their location and number is given in table IV. In the Hakel Forest, the healthy trees of the healthy stand grew at a site about $1.5 \mathrm{~km}$ east of the declining stand, on a 70-cm-deep luvisol over limestone. At all sites, the investigations were carried out in July and August 1993. The distribution of roots was mapped by depth of profile and by diameter of roots by the trench profile wall method (Böhm, 1979). With a small excavator, trenches about $3 \mathrm{~m}$ long, $1 \mathrm{~m}$ wide and 1.3 $m$ deep were dug tangentially at two sides of every oak at $1 \mathrm{~m}$ distance from the stem where, in preliminary investigations (performed in early summer 1993), the oak fine root concentrations had proven to be highest. At the long side of the trench which was orientated towards the tree, root distribution was determined for the rooting depth by counting the number of roots per $\mathrm{dm}^{2}$. After that, soil columns with a ground area of $20 \mathrm{~cm} * 50 \mathrm{~cm}$ were taken from the same profile from three different soil depths: $0-10,10-40$ and $40-70 \mathrm{~cm}$. Two separate samplings were made in each trench. The soil was passed through sieves, and the roots were sorted according to their sizes in finest roots ( $<1 \mathrm{~mm}$ diameter), fine roots (diameter between 1 and $2 \mathrm{~mm}$ ) and small roots (diameter between 2 and $5 \mathrm{~mm}$ ). In the laboratory, fine roots and small roots were, with the aid of binoc- ulars, separated into living roots (root flexible, stele coherent and of white or bright colour) and dead roots (root easily breaking, stele disintegrated and of dark colour). For finest roots, this vitality test was not feasible. The dry weight for every diameter and vitality class (live and dead roots) was determined. Means were calculated from the two replicates of every trench. The means of each trench were used for statistical analyses. For technical reasons, the evaluation of number and portion of mycorrhizal root tips was omitted.

\section{Statistics}

All values are given as means with standard errors if not stated otherwise. Medians and their standard errors are given for the matric potentials measured in Neuenburg in 1992, since in some of the tensiometers, the range of measurement was exceeded during the dry period in summer, and the variance within the stands was rather high at this time. For statistical analyses, the Mann-Whitney ranked sum test (U-test), and the $\mathrm{H}$-test by Kruskal and Wallis for comparisons of more than two sets of observations were employed. The significance level was $5 \%$. For the test of correlation, the equations of regression were calculated, and the coefficients of correlation and regression were tested against the distribution of $t$ values (significance level $5 \%$ ). 
Table IV. Number of trees employed for root investigations at the study sites.

\begin{tabular}{|c|c|c|c|c|c|c|}
\hline \multirow[t]{2}{*}{ Site } & \multicolumn{2}{|c|}{ Healthy stand } & \multicolumn{3}{|c|}{ Declining stand } & \multirow[t]{2}{*}{ Total } \\
\hline & $\begin{array}{c}\text { Healthy } \\
\text { oaks }\end{array}$ & $\begin{array}{c}\text { Moderately } \\
\text { damaged } \\
\text { oaks }\end{array}$ & $\begin{array}{c}\text { Healthy } \\
\text { oaks }\end{array}$ & $\begin{array}{c}\text { Moderately } \\
\text { damaged } \\
\text { oaks }\end{array}$ & $\begin{array}{c}\text { Severely } \\
\text { damaged } \\
\text { oaks }\end{array}$ & \\
\hline Neuenburg & 2 & - & - & 2 & 3 & 7 \\
\hline Hakel/Pansfelde & 2 & - & 2 & 2 & 2 & 8 \\
\hline Sprakensehl & 2 & 1 & 2 & 2 & 2 & 9 \\
\hline
\end{tabular}

\section{RESULTS}

\section{Soil and tree water relations in the pedunculate oak stands in Neuenburg}

\section{Soil water relations}

Due to the high clay content of the subsoil, both of the oak stands showed intermittent soil moisture conditions with stagnant moisture from autumn to early spring. In spring, the upper threshold of stagnant moisture was in a soil depth of 70 to $90 \mathrm{~cm}$ in the healthy stand, but in 40 to $60 \mathrm{~cm}$ depth of the declining stand (for the vegetation period of 1992 , the occurrence of stagnant moisture is given in fig 1). In $40 \mathrm{~cm}$ soil depth, this resulted in significant differences in matric potentials between the healthy and the declining stand in April and in early May 1992 as well as in April and from August to November 1993, the matric potentials being slightly positive at times (figs 1, 2; significant differences, although in part not clearly visible due to the scale chosen, are marked by asterisks). In 1993, stagnant moisture was found from August to November at several dates in the declining, but not in the healthy stand.

The vegetation period in 1992 was warm and dry from mid-May until the end of September with only short periods of fre- quent rainfall. The sum of precipitation from May to August was $240 \mathrm{~mm}$, as opposed to $300 \mathrm{~mm}$ as the average from 1951 to 1980. Accordingly, the soil matric potentials in 15, 40 and $100 \mathrm{~cm}$ soil depth dropped, from mid-May to the beginning of June, from the level of water saturation to about -500 $\mathrm{hPa}$. After a slight increase, as a reaction to rainfall in early July, they reached their most negative values in September (fig 1). In early September, the soil matric potentials were below the range of measurement (ie, below $-850 \mathrm{hPa}$ ) in some of the tensiometers placed in 15 and $40 \mathrm{~cm}$ soil depth of both the healthy and the declining stand. The lowest median values in $100 \mathrm{~cm}$ soil depth were $-744 \mathrm{hPa}$ for the healthy stand (mid-September) and $-764 \mathrm{hPa}$ for the declining stand (end of September).

At the beginning of the dry period, the decrease in soil matric potentials was steeper in the declining stand in both 15 and $40 \mathrm{~cm}$ soil depth, and the matric potentials reached lower (more negative) values. The differences were significant for several dates of measurement (fig 1). In $100 \mathrm{~cm}$ depth, the tendency was the same, but the differences between the stands were smaller.

The vegetation period of 1993 was cool and wet with a precipitation of $326 \mathrm{~mm}$ from May to August (109\% of the average 1951-1980). Accordingly, the most nega- 
Neuenburg, 1992

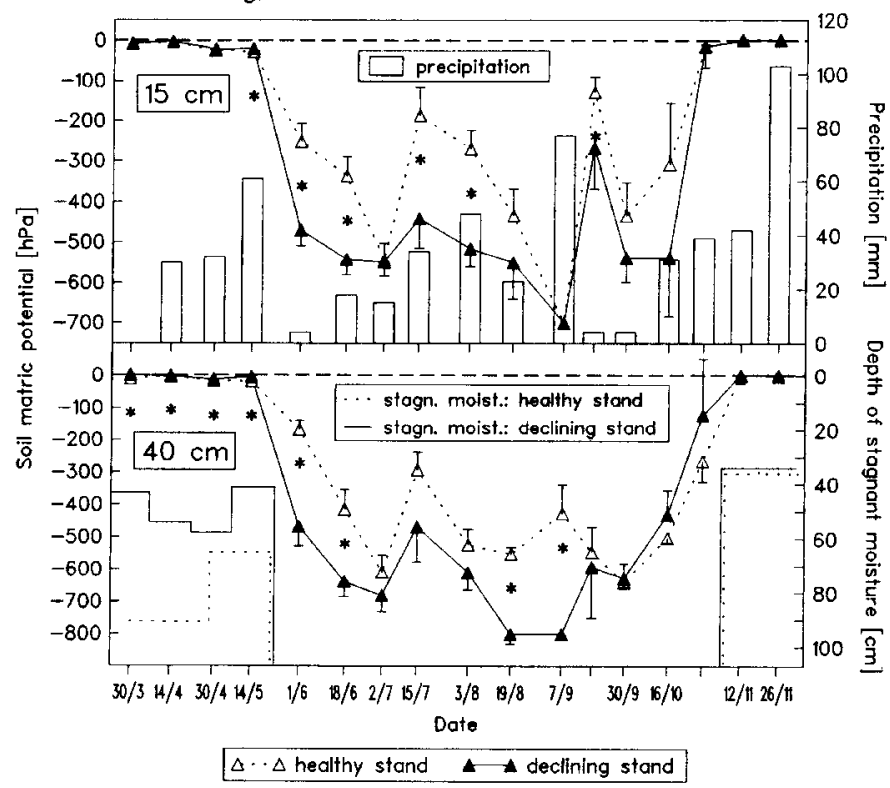

Fig 1. Soil matric potentials in 15 and $40 \mathrm{~cm}$ soil depth of the healthy and the declining pedunculate oak stand in Neuenburg during the vegetation period of 1992 , sums of precipitation between the dates of measurement and depth of stagnant moisture in spring and autumn. * Significant difference between the stands.

Fig 2. Xylem water potentials (at predawn [PWP] and in the afternoon [AWP]) of pedunculate oaks in Neuenburg in July and September 1993, soil matric potentials in $40 \mathrm{~cm}$ soil depth of the healthy and the declining stand during the vegetation period and sums of precipitation between the dates of matric potential measurement. * Significant difference between the stands; $n=$ number of trees. 
tive mean values of soil matric potential were only about $-600 \mathrm{hPa}$ in the healthy stand and $\mathrm{ca}-700 \mathrm{hPa}$ in the declining stand in 40 and $100 \mathrm{~cm}$ soil depth at the beginning of July during a short dry period. Differences between the two sites were most obvious in $40 \mathrm{~cm}$ soil depth (fig 2), but not as distinct as in 1992 (cf fig 1).

\section{Tree water relations and root biomasses}

Despite the fact that soil matric potentials increased from July to September, the PWP decreased during that time except for the healthy oaks of the declining stand which showed a slight increase from July to the beginning of September (fig 2). The decrease in PWP is possibly due to beginning senescence. This would be in accordance with the observation of a distinct decrease of PWP in the severely damaged oak already at the beginning of September, pointing to accelerated senescence. The healthy oak of the healthy stand showed the lowest AWP, which could be measured only in mid-September, indicating a continual transpiration. Apart from this value, no distinct differences were found between healthy and moderately damaged oaks. The AWP-PWP differences determined in midSeptember did not differ significantly between healthy and moderately damaged trees. The PWP and AWP of the moderately damaged oak of the healthy stand, which are not shown in figure 2, were similar to the respective values of the moderately damaged oaks of the declining stand.

In RWC, the most distinct differences were found in comparison of healthy and moderately damaged oaks, irrespective of the degree of damage of the stand. After the short dry period in July, RWC was significantly lower in the leaves from damaged trees (table V). In contrast, the RWC of the severely and the moderately damaged trees were nearly the same. RWC measured at predawn did not fall below $90 \%$.
Although osmotic pressure of leaves from healthy and moderately damaged oaks did not differ significantly (table VI), decreased xylem water potentials were accompanied by lowered (more negative) osmotic pressure in leaves of the damaged trees, but not in leaves from healthy oaks (fig 3 ). (In this case, the water potentials were not corrected by the gravitational potential since the osmotic pressure as well can be influenced by the position of the leaves in the crown [Hinckley et al, 1978].)

At the profiles dug near the healthy oaks, fine roots were found also in more than $1 \mathrm{~m}$ soil depth, with a density of about one root per $\mathrm{dm}^{2}$. In that depth, fine roots could be detected only at one out of five damaged trees, with a density of ca 0.5 roots per $\mathrm{dm}^{2}$. At the other damaged trees, fine roots occurred only down to $100 \mathrm{~cm}$ depth. The comparisons of root biomasses between healthy, moderately damaged and severely damaged pedunculate oaks showed, in all soil depths investigated, an increased percentage of dead fine roots and dead small roots in severely damaged trees (for fine roots, see fig 4). However, the differences were statistically insignificant. In severely damaged oaks, the biomasses of finest roots and live small roots were significantly reduced in 0 to 10 $\mathrm{cm}$ soil depth. The differences between healthy trees and moderately damaged oaks were insignificant except for the finest roots (40 to $70 \mathrm{~cm}$ soil depth; fig 4) and the living small roots $(0$ to $10 \mathrm{~cm}$ soil depth). In these cases, the root biomasses of the healthy trees were higher.

\section{Soil and tree water relations in the sessile oak stands of the Hakel Forest}

\section{Soil water relations}

In 1993, the vegetation period was exceptionally humid. The sum of precipitation from 


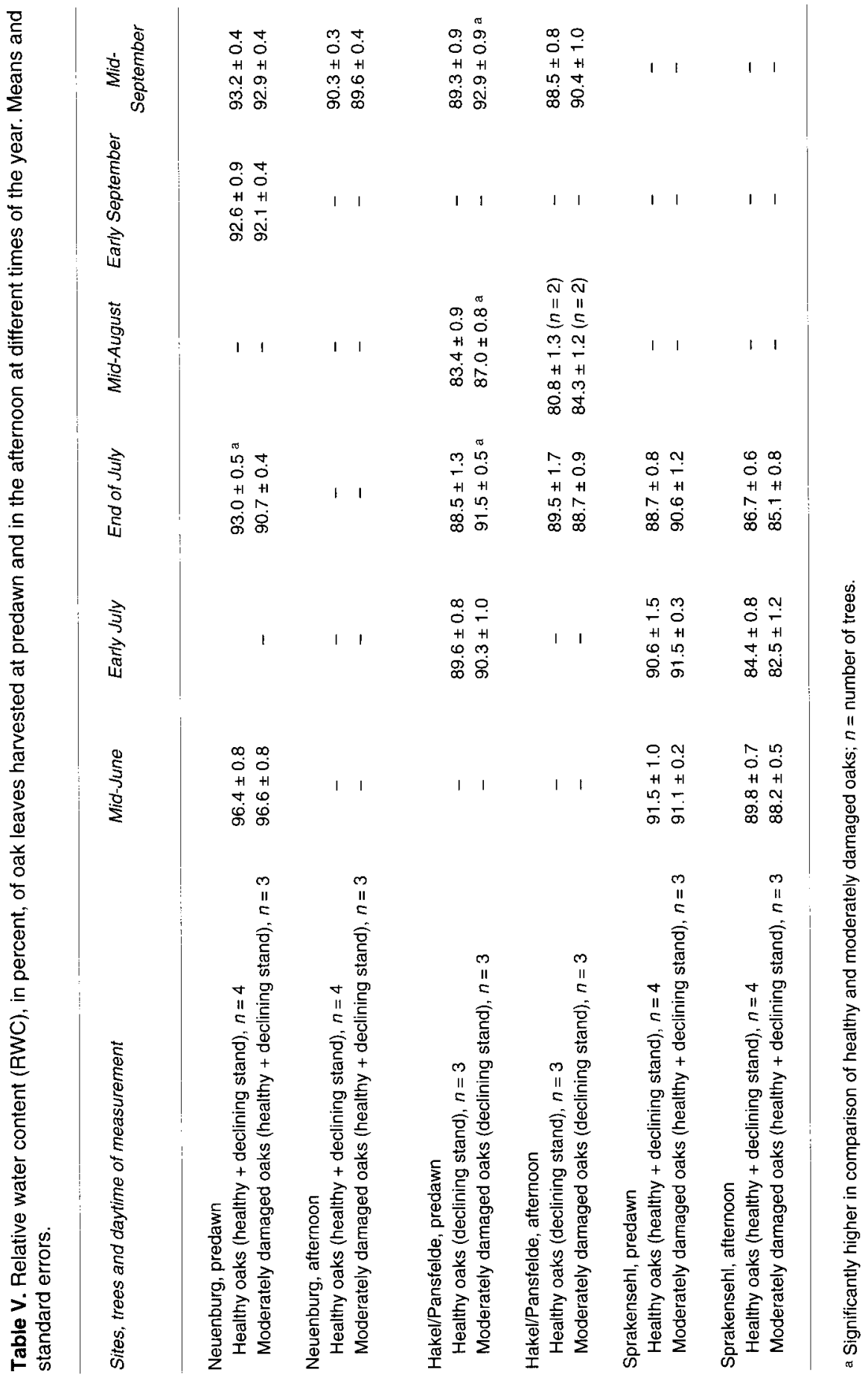


Fig 3. Predawn xylem water potentials and osmotic pressure of leaves from pedunculate oaks in Neuenburg, differing in the degree of damage, at the end of July 1993. Means of the single branches.

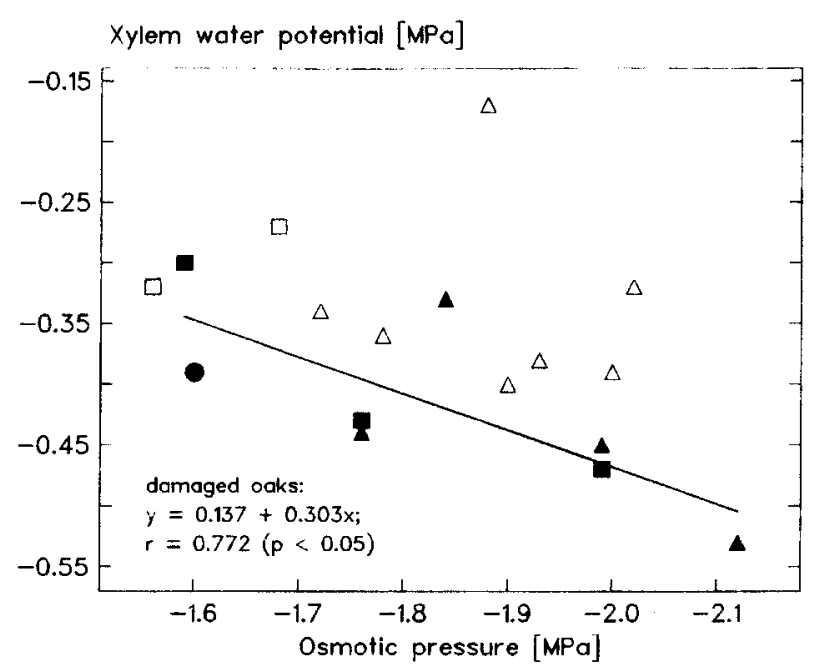

$\square$ healthy oak, healthy stand $\Delta$ healthy oaks, declining stand - mod. dam. oak, healthy stond $\Delta$ mod. dam. oaks, declining stand - severely damaged oak, declining stand

Table VI. Osmotic pressure, in MPa, of cell sap expressed from oak leaves harvested at predawn (Neuenburg, Sprakensehl) and afternoon (Sprakensehl) at different dates in summer. Means and standard errors.

Sites, trees and daytime of measurement Early July

End of July Mid-August

Neuenburg, predawn

Healthy oaks

(healthy + declining stand), $n=4$

Moderately damaged oaks

(healthy + declining stand), $n=3$

$-1.88 \pm 0.10$

Sprakensehl, predawn

Healthy oaks

(healthy + declining stand), $n=4$

Moderately damaged oaks

(healthy + declining stand), $n=3$

$-1.94 \pm 0.08$

$-2.05 \pm 0.02$

$-1.80 \pm 0.05$

$-1.99 \pm 0.03$

Sprakensehl, afternoon

Healthy oaks

(healthy + declining stand), $n=4$

Moderately damaged oaks

(healthy + declining stand), $n=3$

$$
\begin{array}{lll}
-2.07 \pm 0.04 & -2.15 \pm 0.06 & -2.33 \pm 0.03 \\
-2.23 \pm 0.01^{a} & -2.24 \pm 0.02 & -2.39 \pm 0.10
\end{array}
$$

a Significantly higher in comparison of healthy and moderately damaged oaks; $n=$ number of trees. 

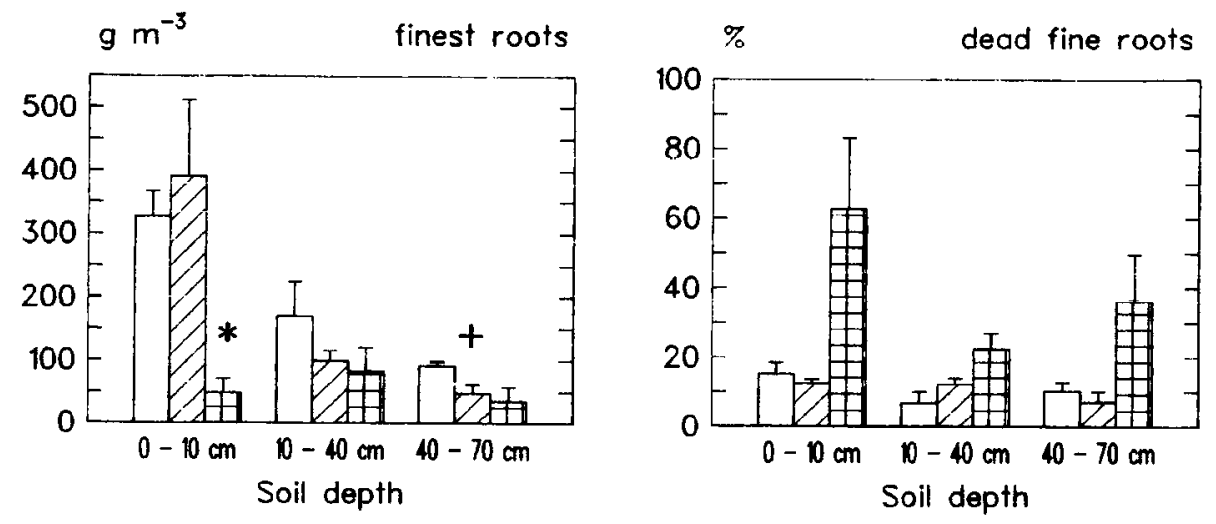

\footnotetext{
$\square$ healthy oaks $(n=4) \quad \square Z 7$ moderately damaged oaks $(n=4)$ 开丑 severely damaged oaks $(n=4)$
}

Fig 4. Biomasses of finest roots and percentage of dead fine roots of pedunculate oaks, differing in the degree of damage, as determined in different soil depths of the stands in Neuenburg. * Significantly lower in comparison of trees of all damage classes; + significantly lower in comparison of healthy and moderately damaged oaks; $n=$ number of trenches.

May to August came to $302 \mathrm{~mm}$ which was $131 \%$ of the average of $1951-1980$. In contrast, the vegetation periods (May to August) of the years 1988-1991 had been relatively dry with $80 \%$ or less of the normal precipitation.

In 15 and $40 \mathrm{~cm}$ soil depth, the matric potentials reacted clearly to dry periods in early July, late August and early September. However, the values did not fall below $-560 \mathrm{hPa}$ (healthy stand) and $-420 \mathrm{hPa}$ (declining stand) in $15 \mathrm{~cm}$ soil depth, and $-620 \mathrm{hPa}$ (healthy stand) and $-515 \mathrm{hPa}$ (declining stand) in $40 \mathrm{~cm}$ depth, respectively. The lowest (most negative) values were reached in $40 \mathrm{~cm}$ depth, but the differences between both stands were insignificant (fig 5). In 60 and $100 \mathrm{~cm}$ soil depth of the healthy stand, the matric potentials decreased more or less uniformly from May to September without falling below -550 $\mathrm{hPa}$ and showed no distinct reactions to changing amounts of precipitation.

\section{Tree water relations and root biomasses}

In July and August, the PWP of damaged oaks tended to lower (more negative) values than in healthy oaks, but the differences were insignificant (fig 5). In August, however, the difference in AWP between healthy and damaged oaks possibly was prevented from being significant by the fact that samples could be taken from only two healthy and two moderately damaged trees. At this time when matric potentials decreased markedly, the lowest AWP were determined (-2.38 and $-2.56 \mathrm{MPa}$ as lowest mean values for a healthy and a damaged tree, respectively, without consideration of the gravitational potential). In the majority of the branches measured at this date, AWP was below -2.2 $\mathrm{MPa}$, irrespective of the degree of damage of the tree. At the dates of measurement, the AWP-PWP differences did not differ significantly between healthy and damaged oaks. 
Fig 5. Xylem water potentials (at predawn [PWP] and in the afternoon [AWP]) of sessile oaks in the Hakel Forest from July to September 1993, soil matric potentials in $40 \mathrm{~cm}$ soil depth of the healthy and the declining stand during the vegetation period and sums of precipitation between the dates of matric potential measurement. Matric potential data from Piep (1994); precipitation data from the meteorological station of Quedlinburg where daily measurements were performed. $n=$ Number of trees.

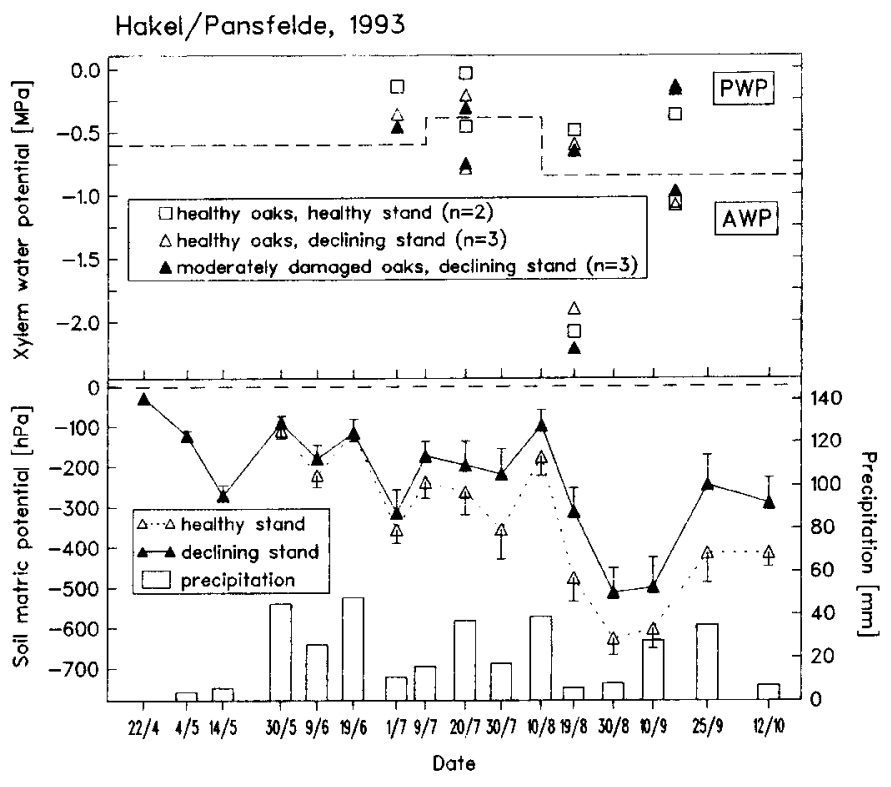

The RWC showed the same seasonal evolution as the xylem water potential, but in contrast, the moderately damaged oaks had, from July to September, significantly higher RWC at predawn than the healthy oaks of the declining stand. Also in the afternoon measurements of August and September, the damaged oaks tended to higher values (table V). The lowest RWC values (mean values for single trees) were found, in late August, in healthy oaks of the declining stand $(81.6 \%$ at predawn and $79.5 \%$ in the afternoon). Damaged oaks showed higher minimum RWC values $(86.0 \%$ at predawn and $83.1 \%$ in the afternoon; determined in late August). A comparison of all means of RWC of the single trees determined from July to September with the respective water potentials shows, however, that damaged trees reacted to a decrease in RWC with a steeper decrease in water potential than healthy trees. This was true for both the predawn and the afternoon measurements (fig 6). However, the regression coefficients calculated for healthy and damaged trees did not differ significantly.
The root densities were nearly the same in healthy, moderately damaged and severely damaged trees. No clear differences were found between the root biomasses of oaks differing in the degree of damage. In 0 to $10 \mathrm{~cm}$ soil depth, the severely damaged trees had a higher percentage of dead fine roots, but the differences were statistically insignificant (fig 7).

\section{Soil and tree water relations in the sessile oak stands in SprakensehI}

\section{Soil water relations}

In early and mid-April, stagnant moisture was found in $100 \mathrm{~cm}$ soil depth adjacent to trees of the healthy stand, but not in the declining stand. A cool and wet spring was followed by extremely warm weeks from the end of June until early August. July was particularly dry with $53 \%$ of the long-term average precipitation (meteorological station of Uelzen). The warm and dry conditions resulted in a steep decrease in soil matric 
potentials at the end of June. Until mid-July, the lowest values were measured in $40 \mathrm{~cm}$ soil depth (fig 8). At the end of July, the matric potentials in $100 \mathrm{~cm}$ depth decreased to the same level as in $40 \mathrm{~cm}$ depth. In early
August, the matric potentials at several tensiometers were below the range of measurement in both 15 and $40 \mathrm{~cm}$ depth. Therefore, soil samples were taken with a borer, and the soil water content was deter-
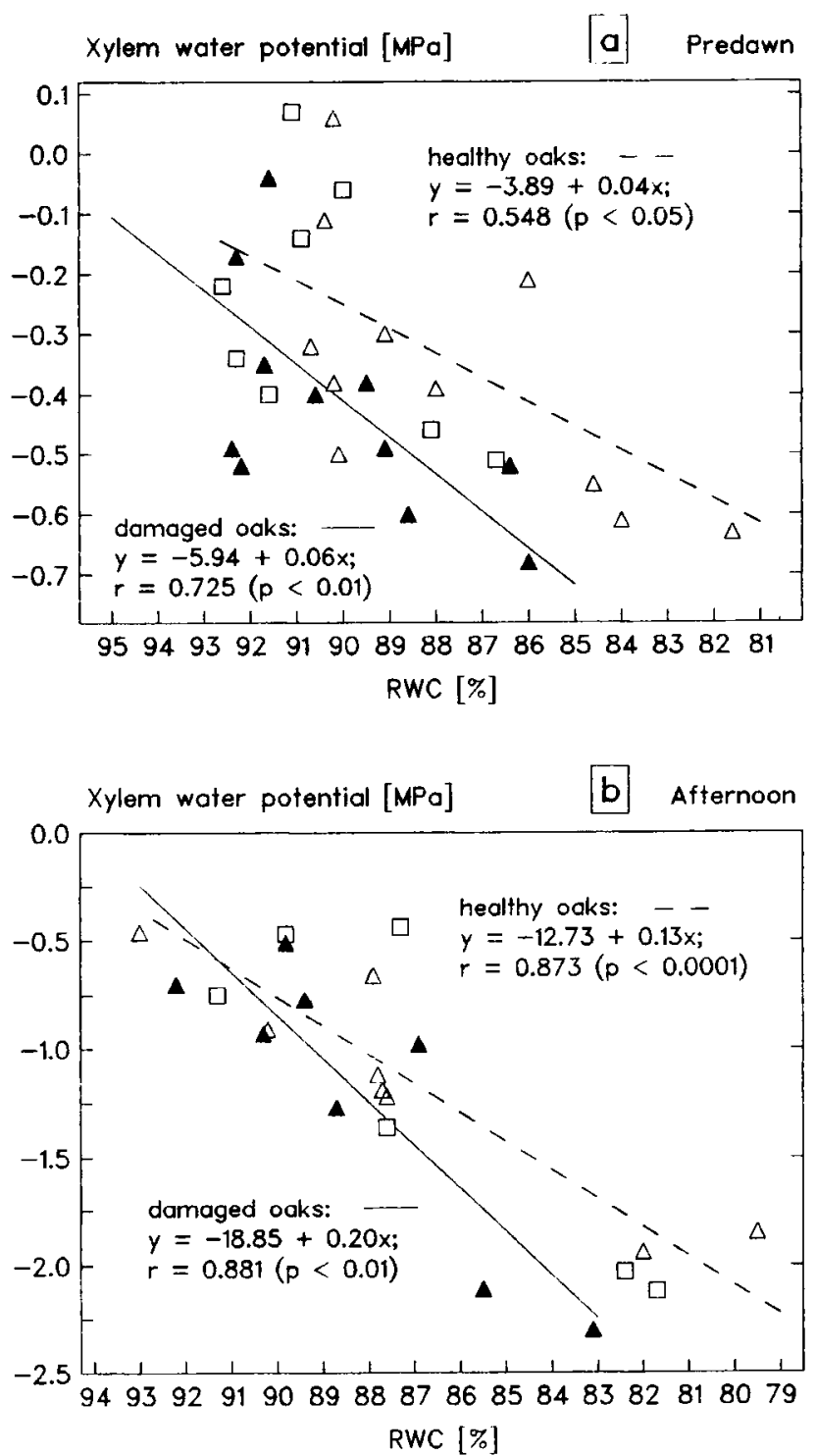

$\square$ healthy oaks, healthy stand $\Delta$ healthy oaks, declining stand $\Delta$ damaged oaks, declining stand
Fig 6. Xylem water potentials, calculated for the stem bases, and relative water contents (RWC) of leaves from healthy and damaged sessile oaks in the Hakel Forest, determined in predawn (a) and afternoon (b) measurements from July to September 1993. Means of the single trees. 

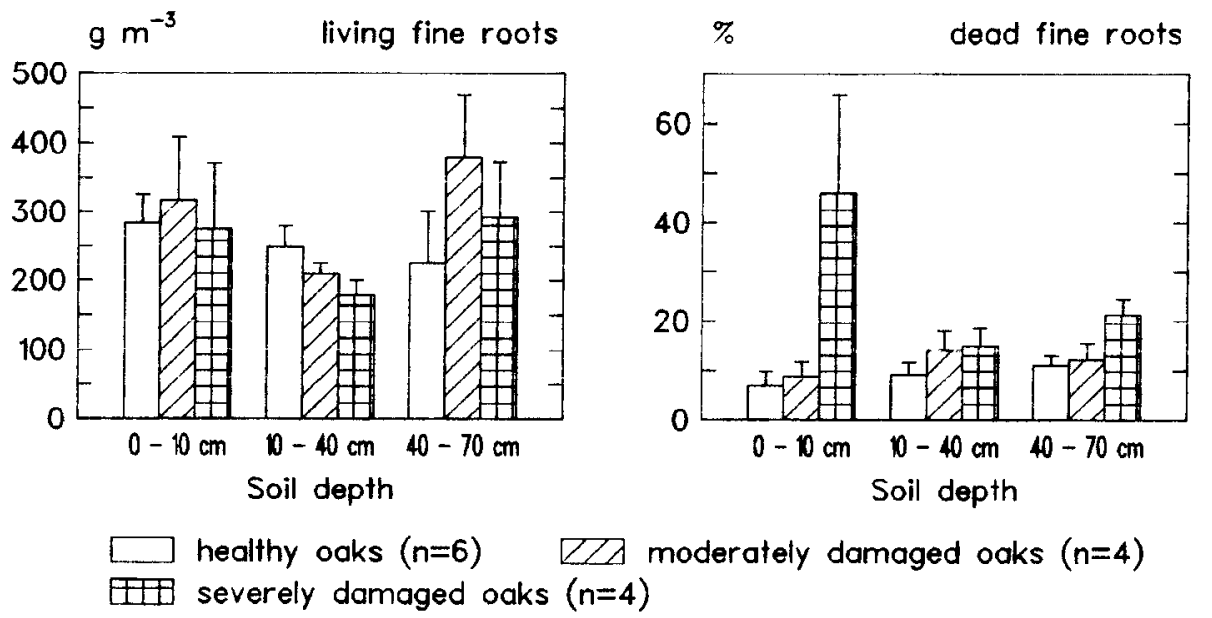

Fig 7. Biomasses of living fine roots and percentage of dead tine roots of sessile oaks, differing in the degree of damage, as determined in different soil depths of the stands in the Hakel Forest. $n=$ Number of trenches.

mined gravimetrically. It was 1.4 to $4.5 \%$ (by weight) in $15 \mathrm{~cm}$ depth, and 1.9 to $3.9 \%$ (by weight) in $40 \mathrm{~cm}$ depth. In $100 \mathrm{~cm}$ depth, the matric potentials were at about -600 $\mathrm{hPa}$ in the healthy and about $-400 \mathrm{hPa}$ in the declining stand at this date. In midAugust, after a cool and wet period, the matric potentials had increased again.

In $40 \mathrm{~cm}$ depth, the lowest values were determined adjacent to the healthy oaks of the declining stand (except for the end of July when the matric potentials near the healthy trees of the healthy stand were lower). The least negative values were obtained near the damaged trees of the declining stand (fig 8).

\section{Tree water relations and root biomasses}

Since the soil water relations had proven to be rather heterogeneous, especially within the declining stand, healthy as well as moderately damaged oaks were combined, irrespective of the degree of damage of the stand, for comparisons of PWP, AWP and
RWC between the vitality classes of the trees. PWP and AWP clearly followed the evolution of soil matric potential (fig 8). At the end of July, after almost 3 weeks with high temperatures and without any precipitation, the PWP of moderately damaged trees were significantly lower than those of healthy trees. At this date, also the lowest PWP and AWP were measured. The lowest mean values of a single tree were -0.87 and $-0.94 \mathrm{MPa}$ in a healthy and a damaged oak, respectively, at predawn, and -2.67 and $-2.54 \mathrm{MPa}$ in a healthy and a damaged oak, respectively, in the afternoon (gravitational potentials taken into account). Without consideration of the gravitational potential, the AWP of all branches measured were below $-2.30 \mathrm{MPa}$ with the most negative value being $-3.07 \mathrm{MPa}$ in one healthy tree. Apart from that, no clear differences were detected between the xylem water potentials of healthy and damaged oaks. The AWP-PWP differences did not differ significantly between healthy and moderately damaged trees. Except for mid-June, the xylem water potentials of the severely dam- 


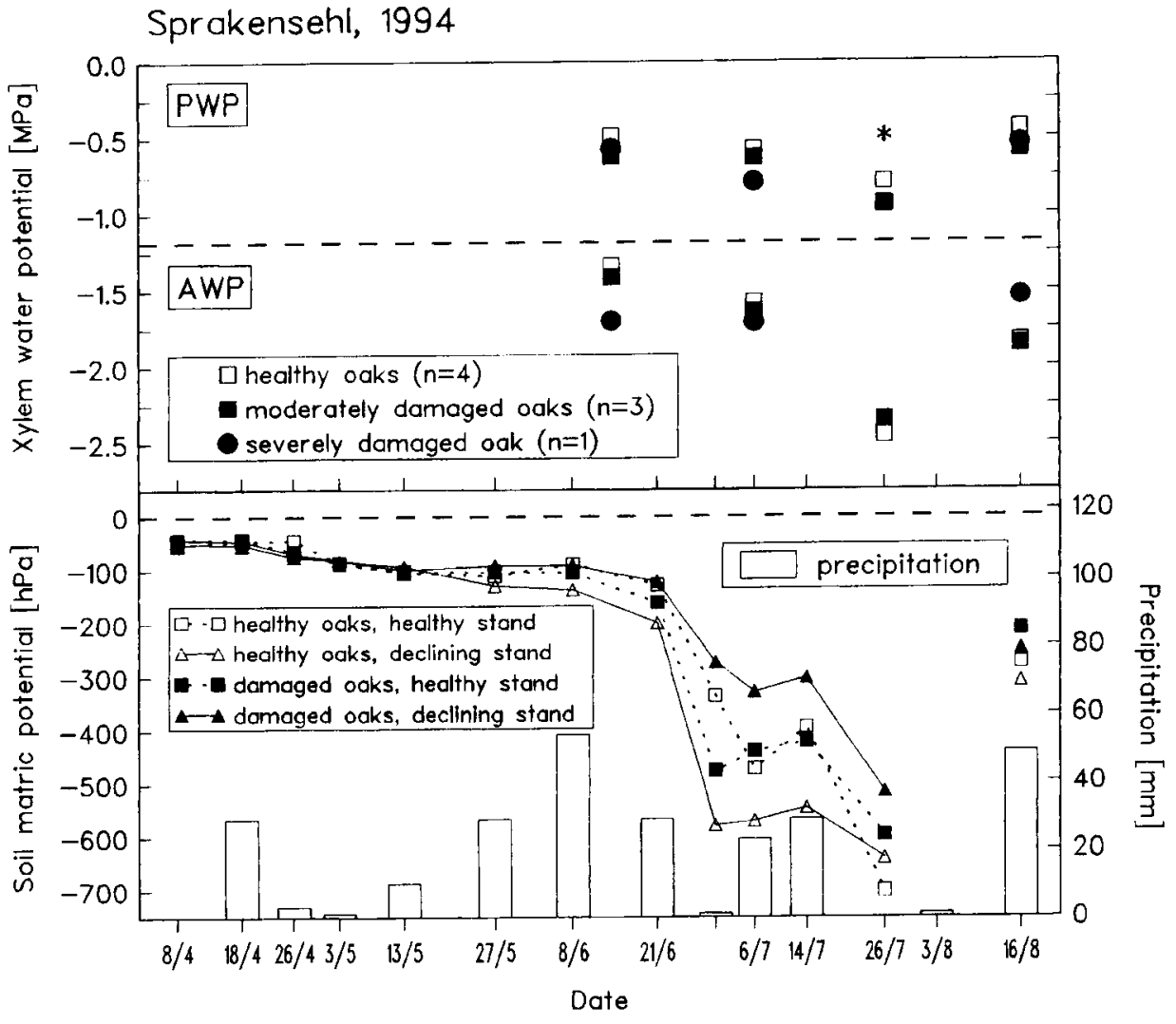

Fig 8. Xylem water potentials (at predawn [PWP] and in the afternoon [AWP]) of sessile oaks in Sprakensehl from June to August 1994 , soil matric potentials of $40 \mathrm{~cm}$ soil depth at $1 \mathrm{~m}$ distance from the stems, and sums of precipitation between the dates of matric potential measurement. Precipitation data are derived from the meteorological station of Soltau ( $45 \mathrm{~km}$ northwest of Sprakensehl) where daily measurements were performed. ${ }^{*}$ Significant difference; $n=$ number of trees.

aged oak were not distinctly lower than those determined in healthy and moderately damaged trees.

The RWC values measured at predawn were at a relatively high level even at the end of July (table V). The RWC determined in the afternoon tended to be lower in moderately damaged oaks, but the differences were insignificant. The lowest values were ca $81 \%$ in the damaged oaks from the healthy stand (afternoon, early July). The osmotic pressure of the afternoon mea- surements were lower than the predawn values for every tree investigated. In moderately damaged oaks, the values tended to be lower. In early July (afternoon measurements) and mid-August (predawn measurements), the differences were significant (table VI). At the end of July, the osmotic pressure of the leaves from damaged trees tended, at comparable levels of RWC, to be lower than the respective values obtained from healthy trees in both predawn and afternoon measurements (fig 9). 
In the soil profiles dug near the damaged oaks, fine roots were found in more than $1 \mathrm{~m}$ soil depth, with densities between ca 0.4 and 2 roots per $\mathrm{dm}^{2}$. At these depths, no fine roots could be detected in trenches excavated near healthy oaks. The occur- rence of finest and fine roots in the subsoil often was restricted to layers with a higher clay content which were found not only near healthy but also underneath damaged oaks. Related to the soil volume, the biomasses of finest roots and living fine roots did not dif-

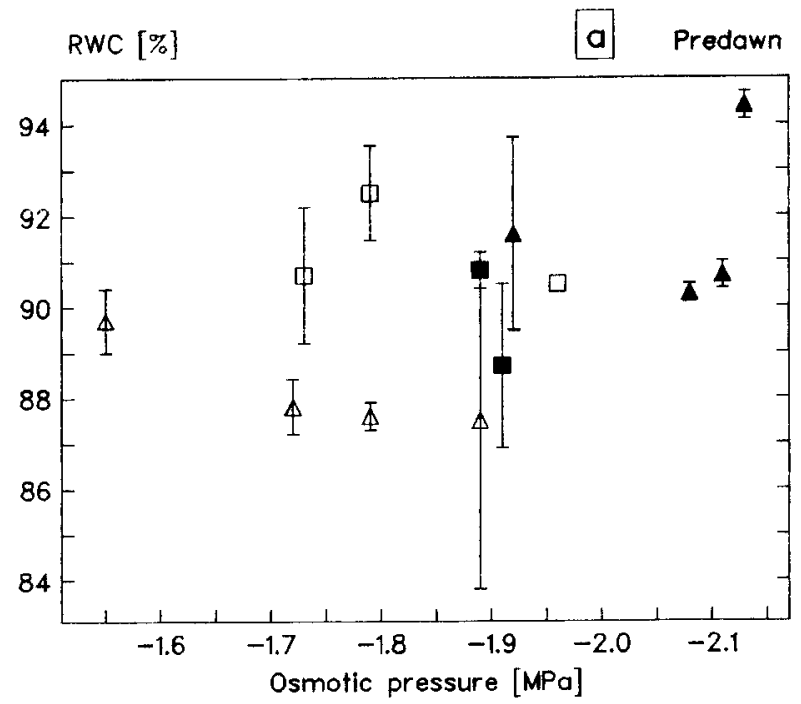

Fig 9. Relative water content (RWC) and osmotic pressure of leaves from healthy and moderately damaged sessile oaks in Sprakensehl, measured at the end of July 1994 at predawn (a) and in the afternoon (b). Means of single branches.

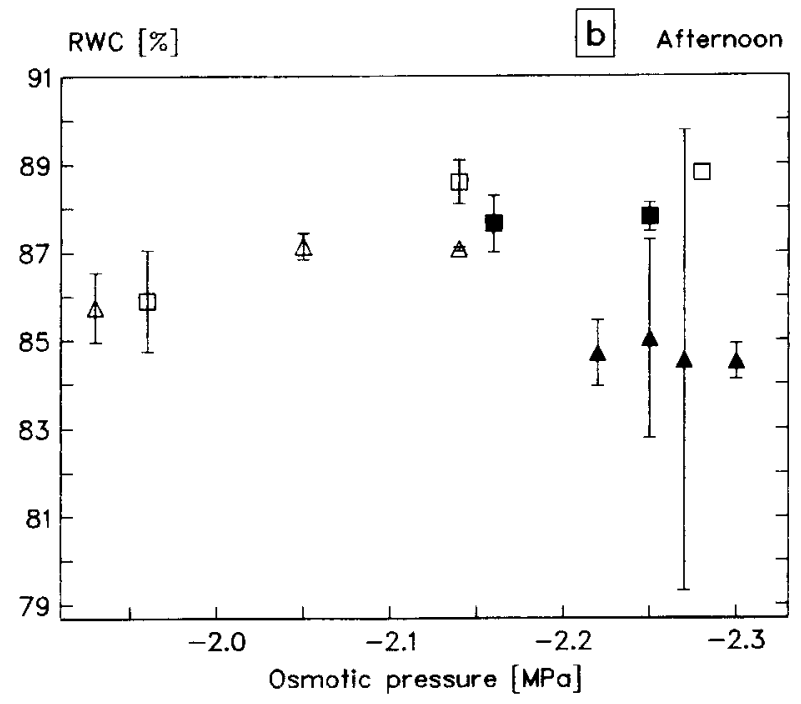

$\square$ healthy oaks, healthy stand $\Delta$ healthy oaks, declining stand - damaged oaks, healthy stand $\Delta$ damaged oaks, declining stand 


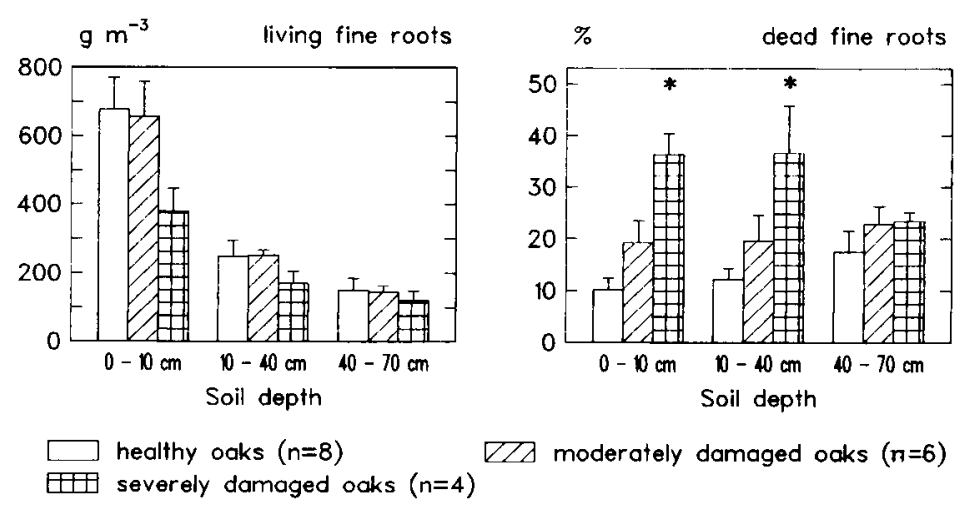

Fig 10. Biomasses of living fine roots and percentage of dead fine roots of sessile oaks, differing in the degree of damage, as determined in different soil depths of the stands in Sprakensehl. * Significantly higher in comparison of trees of all damage classes; $n=$ number of trenches. fer between trees varying in the degree of damage. In contrast, the severely damaged oaks had significantly more dead fine roots in 0 to $10 \mathrm{~cm}$ soil depth as well as a higher percentage of dead fine roots in 0 to 10 and 10 to $40 \mathrm{~cm}$ depth (fig 10 ). Moderately damaged trees showed significantly more decayed fine and small roots and a higher percentage of dead small roots in 0 to 10 $\mathrm{cm}$ soil depth, compared to healthy oaks.

\section{DISCUSSION}

\section{Soil water relations}

In all stands investigated, distinct reactions of soil matric potentials of the upper soil $(0-40 \mathrm{~cm}$ depth) to dry periods were detected, but only in the pedunculate oak stands of Neuenburg, a higher degree of oak damage corresponded with steeper decrease and lower minimum values of matric potential. The lower threshold of the range of readily exploitable soil water is commonly set at ca $-680 \mathrm{hPa}$. Soil water bound by potentials below this value is not as readily available (Richard et al, 1978). In Neuenburg, the soil matric potentials of the declining stand fell below $-680 \mathrm{hPa}$ in 40 $\mathrm{cm}$ soil depth for 3 weeks during the dry vegetation period of 1992 and, for a shorter period, during the wet growing season of 1993. Since a considerable amount of finest and fine root biomass was found in 10 to $40 \mathrm{~cm}$ soil depth, decreased water availability in this horizon is likely to affect the water supply of the trees. Moreover, the matric potentials were, compared to the healthy stand, distinctly lowered also in the uppermost soil layer where the concentration of finest roots of the moderately damaged trees was highest. In the subsoil (below $40 \mathrm{~cm}$ ) of the declining stand where the exploitable water capacity, compared to the healthy stand, was reduced, the concentration of finest roots was decreased. Obviously, the reason for both of these findings is the high clay content of this horizon. In addition, stagnant moisture was found in lesser soil depths and for longer periods in the declining stand, compared to the healthy stand. This is likely to lead to a drastically decreased $\mathrm{O}_{2}$ concentration of the soil which results in a hindered root growth (Kozlowski, 1979). Possibly, this contributes to a restriction in water supply in following dry periods.

It is clear that the soil matric potentials were far above the critical threshold of about $-0.7 \mathrm{MPa}$ below which the growth of tree roots stops (Waring and Schlesinger, 1985). The differences between the healthy and 
the damaged stand, however, are evident. Interestingly, recent studies on saplings of Norway spruce (Picea abies) showed that the colonization or infection of fine roots under drought stress (soil matric potentials not below $-700 \mathrm{hPa}$ ) by potentially pathogenic microfungi was distinctly higher than in well watered plants (Kattner, 1992). Theoretically, infection of roots by fungi under drought conditions could play a role as a concomitant factor also in oak decline. Observations of that kind were not made in the root investigations of 1993. This was, however, a cool and wet year in which drought stress could not develop.

In contrast to Neuenburg, the most negative soil matric potentials in the Hakel Forest and in Sprakensehl were found in the healthy stand or near healthy trees, respectively. This is probably due to the different soil texture. In the Hakel Forest, the soil consisted of loess which has, in the range between -0.01 and $-0.0 \mathrm{MPa}$, the highest water conductivity (Schachtschabel et al, 1984). Healthy, strongly transpiring trees can, therefore, lower the water content and, thus, the matric potential of this soil to a great extent. In sandy soils, the water content is drastically reduced already at relatively high matric potentials $(<10 \%$ water [vol/vol] at $-100 \mathrm{hPa}$ ). Above $-100 \mathrm{hPa}$, water conductivity is very high, but decreases steeply below that threshold (Schachtschabel et al, 1984). Again, the healthy trees in Sprakensehl obviously can lower both water content and matric potential of the soil to a greater extent than damaged oaks. In the declining stand of Neuenburg, however, the soil water is bound firmly due to the high clay content, and a removal of a relatively small amount of water, in the range of -0.01 to $-0.1 \mathrm{MPa}$, results in a considerable decrease in matric potential. In contrast, water supply is more favourable in the healthy stand with a thicker layer of loamy sand and lower clay content in the subsoil.

\section{Tree water relations}

For the maintenance of leaf turgescence, the relative water content has to be kept within a certain range. For the vast majority of plants, the turgor loss point is supposed to be in the RWC range of 75 to $85 \%$ (Bradford and Hsiao, 1982). In Neuenburg, the RWC of leaves was distinctly above this range, but damaged oaks reacted even to short dry periods within a cool and wet growing season with a decrease in RWC, although soil matric potentials did not fall below $-800 \mathrm{hPa}$. It can be assumed that site conditions vary to a certain extent within both stands, leading to differences also in water relations of the trees. This could be the reason for the differences in RWC between leaves of healthy and of damaged oaks, irrespective of the stand in which they grew.

One mechanism for the maintenance of the RWC during water stress is 'osmotic adjustment', that is, active accumulation of osmotically effective substances in the vacuole, resulting in a decrease in osmotic pressure (which becomes more negative). In contrast to healthy oaks, the osmotic pressure decreased in leaves of damaged trees with decreasing xylem water potential (fig 3). However, at the same levels of RWC, the osmotic pressure of leaves from damaged oaks were not lower than those of healthy oaks. The determination of osmotic pressure by expression of the cell sap leads to a dilution by apoplasmic water; however, under the assumption that the dilution effect was nearly the same in healthy and damaged oaks, it can be concluded that the lowered osmotic pressure in the leaves of damaged oaks were caused by the reduction in water content of the leaves and not actively by osmotic adjustment. However, osmotic adjustment was found to occur in waterstressed seedlings of Quercus robur (Osonubi and Davies, 1978). Most probably, the extent of the dry period in 1993 was 
not sufficient to trigger this reaction, or the delay between that period and the date of measurement was too long.

In the oaks of the Hakel Forest, during a dry period with decreasing soil matric potentials, distinctly lower xylem water potentials than in the trees in Neuenburg were measured, the values being below $-2.2 \mathrm{MPa}$ in the majority of branches. Below $-2.0 \mathrm{MPa}$, the extent of cavitation increases in sessile oak, resulting in an increased loss of hydraulic conductivity (Cochard et al, 1992). However, a certain loss of hydraulic conductivity occurs also without any drought stress (Cochard and Tyree, 1990). Therefore, a xylem water potential corresponding to $50 \%$ loss of conductivity often is taken as an indication of drought-induced cavitation. In sessile oak, this critical xylem water potential is $-3.3 \mathrm{MPa}$ (Cochard et al, 1992). The water potentials determined in the Hakel Forest were above that value and, thus, do not point to water stress. However, no measurements were performed in the period with the lowest soil matric potentials. The lowest RWC values determined were already within the range in which turgor loss can occur, but the leaves harvested were still turgescent. Moreover, RWC often was higher in leaves from damaged oaks than in those of healthy trees of the declining stand. In these trees, the lowest RWC values were reached. It is likely that the water supply of the shallow soil is, at least at times, insufficient for trees with well developed, strongly transpiring crowns. In damaged oaks, the maintenance of RWC at a higher level and, thus, above the critical threshold could have been achieved by the following reactions: i) reduction of the xylem water potential to a somewhat greater extent than in healthy oaks (cf Tree water relations and root biomasses) (perhaps due to osmotic adjustment); ii) by a reduced bud formation in dry years, resulting in decreased twig and leaf biomass and, thus, in a reduced transpiring surface in the following year; iii) by shedding of leaves and twigs in dry years, thereby reducing the transpiring biomass. Shedding of twigs with green leaves has been often observed in oak; it seems to be favoured by warm and dry years and can start in July, reaching its maximum in autumn (Huber, 1955).

Also in Sprakensehl, the critical xylem water potential corresponding with $50 \%$ loss of hydraulic conductivity was never reached, not even in the period of the most intensive drought. The maintenance of RWC of leaves from damaged oaks at the same level as in leaves from healthy trees apparently was achieved, like in the Hakel Forest, by a slightly stronger decrease in xylem water potential (end of July, at predawn). The reduction, in tendency, of the osmotic pressure of leaves from damaged oaks (significantly at two dates) may have contributed to this reaction. The tendency of damaged oaks to lower (more negative) osmotic pressure could also be the reason for the fact that their PWP tended to lower values than PWP in healthy trees, although soil matric potentials were less negative adjacent to damaged oaks. The results point to osmotic adjustment as the cause for the lowered osmotic pressure, but further studies would be necessary to prove this hypothesis. The reduction in PWP and osmotic pressure could have been caused by i) a reduced soil water conductivity in the surroundings of damaged trees (due to site variations within the stand); ii) a reduced ability to water uptake by the roots: this seems rather improbable since distribution and biomass of finest and fine roots of (moderately) damaged trees were not lower than in healthy oaks; iii) larval feeding of Agrilus biguttatus Fabr, leading to impairment of water conductivity by induction of tylosis of earlywood vessels. Attacks by Agrilus are sometimes hard to discover, but occur very often at rather early stages of decline (Hartmann and Blank, 1992). Jaquiot (1950) found, as a result of Agrilus attack, an abnormal wood formation over several years with xylem elements severely reduced in number and size. 
However, further studies on the effect of larval feeding of Agrilus on hydraulic conductivity are needed.

Interestingly, the lowest RWC values determined in Sprakensehl were still higher than those measured in the Hakel Forest where both soil matric and xylem water potentials were less negative. Possibly, a critical threshold below which osmotic adjustment starts was, due to drought, exceeded in Sprakensehl, but not in the Hakel Forest. The assumption of osmotic adjustment would also explain the finding of the tendency to lowered osmotic pressure, at the same level of RWC, in leaves from damaged oaks compared to leaves from healthy trees (fig 9).

The leaf water potential (measured as the xylem water potential) and the osmotic pressure given, the turgor pressure can be calculated according to the equation of the water relation of cells and tissues. Under the assumption that the dilution effect caused by apoplasmic water is of the same extent in both healthy and damaged oaks, the turgor pressures of trees differing in the degree of damage can be compared. No differences between healthy and moderately damaged oaks were found. This supports the conclusion that healthy and damaged oaks did not differ in the water status of the leaves. Furthermore, it is in accordance with other studies (Cochard et al, 1992; Lévy et al, 1992; Bréda et al, 1993) having shown sessile oak to be relatively drought tolerant.

\section{The role of water relations in oak damage}

From the results it can be concluded that edaphic conditions as well as genetic differences between the two oak species affect the susceptibility of the trees to water stress. For the pedunculate oak stand in Neuenburg, the following complex of factors lead- ing to decline can be postulated: at the declining stand, the edaphic conditions (subsoil with a high clay content, covered by only a thin layer of loamy sand) lead to both prolonged periods of stagnant moisture and, in late spring and summer, to relatively low exploitable water stock. Besides the higher mechanical resistance of the clayey soil, these are the probable reasons for the reduced biomass of finest roots observed in the subsoil of the declining stand. By the reduction in root biomass, the water availability is further restricted at this stand. It has to be expected that the unfavourable soil water relations of the declining stand affect the growth also of healthy trees. Indeed, measurements had shown that, during the last 75 years, the annual latewood increment of healthy oaks of the declining stand was distinctly smaller than that of healthy oaks of the healthy stand. (In this context, latewood width is more sensitive than tree ring width since its production is much more influenced by external factors than the formation of earlywood which is generated each year with only minor fluctuations [Blank, 1996].)

It can be assumed that it is the microsites with the most unfavourable soil water relations where the relative water contents of the leaves are reduced. The fact that differences in RWC did occur, after a short dry period, even within a cool and wet summer leads to the conclusion that differences between healthy and damaged oaks will become even greater in years with marked dry periods as did occur in that region at least four times between 1983 and 1992. Therefore, drought can be regarded as a preconditioning factor of oak decline at this site. This conclusion is consistent with the fact that drought, insect defoliation and frost coincided with the last outbreak of decline in Neuenburg in 1985/86 as was revealed by dendrochronological analyses (Hartmann and Blank, 1992, 1993). Thus, also the finding by Ackermann and Hartmann (1992) of increased damage in oak stands, particu- 
larly of pedunculate oak, at sites with stagnant or intermittent soil moisture conditions, is confirmed. Moreover, a recent CIR-aerial survey of 63 ha of stands of adult pedunculate oaks in the forest district of Neuenburg, comprising a wide range of different water relations, revealed the most damage (dead trees, or more than $50 \%$ leaf loss) to occur at boggy sites. The least damage, however, was found at sites uninfluenced by ground water or stagnant moisture (Ackermann, unpublished data). This finding shows that the risk of damage is increased at sites with distinct changes in water relations throughout the year. Having investigated oak decline in the Netherlands, Oosterbaan (1991) came to similar results.

In contrast to the pedunculate oak stand in Neuenburg, the results presented for the sessile oak stands do not point to a considerable contribution of water stress to the actual decline. This assessment is supported by results of dendrochronological investigations which led to the conclusion that, concerning sessile oaks, factors like insect defoliation and/or frost are more important for decline than drought. In the Hakel Forest, the least severe reduction in tree ring growth during the last 20 years coincided with the occurrence of drought. More severe reductions obviously were due to insect defoliation, and the most severe reductions were found for years with insect defoliation and drought occurring at the same time (Blank, 1996). In Sprakensehl, the actual outbreak of decline in 1986/87 was accompanied by severe winter frost and defoliation, while drought occurred in the following years (Hartmann and Blank, 1992, 1993). If the crown reduction of oaks in the Hakel Forest, but maybe also in Sprakensehl, is an adaptation to periods of shortage in water supply, and if trees do recover in following years with sufficient precipitation, this process of crown thinning has to be differentiated from 'oak decline' in its true sense, which leads to the death of the tree within a rather short time.
The finding of a lesser impact of drought on sessile oak is in accordance with the general assessment of this species of having a lower water requirement than pedunculate oak (Krahl-Urban, 1959), and with studies having shown sessile oak to be more drought tolerant than pedunculate oak (cf Tree water relations). Also in Hungary, no primary connection between the occurrence of drought and the outbreak of sessile oak decline could be found (Führer, 1992). In France, sessile oak was, at least in mixed stands, less affected by the severe drought of 1976 than pedunculate oak (Lévy et al, 1992).

Since distribution and biomasses of fine roots and the percentage of dead fine roots generally did not differ significantly between moderately damaged oaks and healthy trees, it can be assumed that root damage is not a primary factor in oak decline. Significant reductions of fine root biomasses or increase in the percentage of dead fine roots were found almost exclusively in severely damaged oaks and, thus, in a later stage of decline. However, further studies are necessary which will have to focus on the vitality of finest roots and their impairment by facultative and obligatory pathogenes.

\section{ACKNOWLEDGMENTS}

This research is supported by the German Bundesministerium für Forschung und Technologie (BMFT), Project no 0339382A. The authors are responsible for the content of the publication. We thank the state of Lower Saxony and the Bundesanstalt für Arbeit for granting financial support to a provision of work (ABM). We wish to thank Dipl Forstw R Blank, Niedersächsische Forstliche Versuchsanstalt, for conducting tree-ring analyses, Prof Dr M Popp and cand biol T Große Schultze, Universität Münster, Institut für Angewandte Botanik, for the determination of osmotic pressure in leaf samples from Neuenburg; and the technical assistants K Herwig and M Pape, Niedersächsische Forstliche Versuchsanstalt, for 
considerable help in the determination of water potentials. The helpful comments of reviewer 2 on the manuscript are greatly appreciated.

\section{REFERENCES}

Ackermann J, Hartmann G (1992) Survey of crown damage in oak stands of Lower Saxony/NW-Germany by CIR-aerial photography in 1988/89. Forst Holz 47, 452-460 [in German with English summary]

Arbeitskreis Standortskartierung, ed (1980) Forstliche Standortsaufnahme, 4th edn. Landwirtschaftsverlag, Münster-Hiltrup, Germany

Backes K (1991) Vergleichende Untersuchungen zum Wasserhaushalt von Buche und Eiche in einem Mischbestand. Diploma thesis, Univ Göttingen, Systematisch-Geobotanisches Inst, Germany

Becker M, Lévy G (1982) Le dépérissement du chêne en forêt de Tronçais. Les causes écologiques. $\mathrm{Ann} \mathrm{Sci}$ For 39, 439-444

Blank R (1996) Jahrringanalytische Untersuchungen an Eichen in Nordwestdeutschland unter besonderer Berücksichtigung des Einflusses der Eichenwicklerschadgesellschaft. Thesis, Univ Göttingen, Inst für Waldbau (in preparation)

Böhm W (1979) Methods of Studying Root Systems Vol 33. Ecological Studies. Springer, Berlin

Bradford KJ, Hsiao TC (1982) Physiological responses to moderate water stress. In: Encyclopedia of Plant Physiology (OL Lange, PS Nobel, CB Osmond, $\mathrm{H}$ Ziegler, eds), Springer, Berlin, New Series, Vol 12 B, 263-324

Bréda N, Cochard H, Dreyer E, Granier A (1993) Water transfer in a mature oak stand (Quercus petraea). seasonal evolution and effects of a severe drought. Can J For Res 23, 1136-1143

Cochard H, Tyree MT (1990) Xylem dysfunction in Quercus: vessel sizes, tyloses, cavitation and seasonal changes in embolism. Tree Physio/ 6, 393-407

Cochard H, Bréda N, Granier A, Aussenac G (1992) Vulnerability to air embolism and hydraulic architecture of three European oak species (Quercus petraea [Matt] Liebl, $Q$ pubescens Willd, $Q$ robur $L$ ). Ann Sci For 49, 225-233

Delatour C (1983) Les dépérissements de chênes en Europe. Rev For Fr 35, 265-282

Deutscher Wetterdienst (1992-1994) Monaticher Witterungsbericht. Deutscher Wetterdienst, Offenbach

Eisenhauer DR (1989) Untersuchungen zur Entwick lung der ökologischen Stabilität von Eichenbeständen im nordöstlichen Harzvorland. Beitr Forstwirtsch $23,55-62$
Führer EG (1992) The connection between drought and the decline of sessile oak stands in Hungary. Forstw Cb/111, 129-136 [in German with English summary]

Hartmann G, Blank R (1992) Winter frost, insect defoliation and Agrilus biguttatus Fabr as causal factors of oak decline in northern Germany. Forst Holz 47, 443-452 [in German with English summary]

Hartmann G, Blank R (1993) Etiology of oak decline in northern Germany. History, symptoms, biotic and climatic predisposition, pathology. In: Recent Advances in Studies on Oak Decline (N Luisi, P Lerario, A Vannini, eds), Proceedings Internat Congress, Selva di Fasano (Brindisi), Italy, 13-18 September 1992. Dipartimento di Patologia vegetale, Bari, 277 284

Hinckley TM, Lassoie JP, Running SW (1978) Temporal and Spatial Variations in the Water Status of Forest Trees. Forest Science Monograph 20. Society of American Foresters, Washington, DC, USA

Huber B (1955) Zweigabsprünge. Allg Forst Z 10, 620621

Jaquiot C (1950) Des relations entre les attaques d'Agrilus biguttatus Fabr et certains cas de dépérissement des chênes. Rev Path Vég Entomol Fr 29, 171182

Kattner D (1992) The influence of drought stress on the colonization of fine roots of Norway spruce (Picea abies Karst) by Trichoderma viride and other endogenous microfungi. Forstw Cb/111, 383-389 [in German with English summary]

Kozlowski TT (1979) Tree Growth and Environmental Stresses. University of Washington Press, London, Seattle

Krahl-Urban J (1959) Die Eichen. Parey, Hamburg

Lévy G, Becker M, Duhamel D (1992) A comparison of the ecology of pedunculate and sessile oaks: radial growth in the centre and northwest of France. For Ecol Manage 55, 51-63

Oosterbaan A (1991) Investigations on oak decline in the Netherlands (1986-1990). In: Oak Decline in Europe (R Siwecki, W Liese, eds), Proceedings Internat Symposium Kórnik, Poland, 15-18 May 1990. Poznan, 61-67

Osonubi O, Davies WJ (1978) Solute accumulation in leaves and roots of woody plants subjected to water stress. Oecologia 32, 323-332

Piep $H$ (1994) Untersuchungen zum Wasserhaushalt von Traubeneichenbeständen und seine Beziehung zum Eichensterben im Mitteldeutschen Trockengebiet am Beispiel des Hakel-Waldes. Diploma thesis, Univ Göttingen, Inst für Waldbau

Richard F, Lüscher P, Strobel T (1978) Physikalische Eigenschaften von Böden aus der Schweiz, Vol. 1. Eidgen Anst Forstl Versuchswes, Birmensdorf, Switzerland 
Schachtschabel P, Blume HP, Hartge KH, Schwertmann U (1984) Scheffer/Schachtschabel - Lehrbuch der Bodenkunde, 11th edn. Enke, Stuttgart

Schlag MG (1994) Oak decline in Europe and its causes as seen from a phytopathological point of view. $C b /$ Ges Forstwesen 111, 243-266 [in German with English summary]

Slavik B (1974) Methods of Studying Plant Water Relations. Ecological Studies. Vol 9. Springer, Berlin
Thomas FM, Büttner G (1993) Excess nitrogen, drought, and winter frost as possible predisposing factors of oak decline in northern Germany. In: Recent Advances in Studies on Oak Decline (N Luisi, P Lerario, A Vannini, eds), Proceedings Internat Congress, Selva d Fasano (Brindisi), Italy, 13-18 September 1992, Dipartimento di Patologia vegetale, Bari, 285-291

Waring $\mathrm{RH}$, Schlesinger WH (1985) Forest Ecosystems: Concepts and Management. Academic Press, Orlando, FL 